\title{
The Relevance Analysis of Accounting Information, Corporate Social Responsibility and Leverage as Moderating Variables
}

Indhung Listyaningrum ${ }^{1}$

${ }^{1}$ Department of Accounting-Economic Faculty-Universitas Islam Batik Surakarta-Indonesia Kartika Hendra Titisari ${ }^{2}$, Siti Nurlaela ${ }^{3}$

${ }^{2}$ Department of Accounting-Economic Faculty-Universitas Islam Batik Surakarta-Indonesia;

${ }^{3}$ Department of Accounting-Economic Faculty-Universitas Islam Batik Surakarta-Indonesia;

\section{Correspondence : Indhunglistyaningrum@gmail.com}

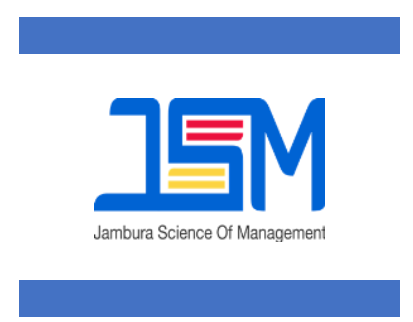

JSM

Volume 3

Number 2

July 2021.

Received on 8 July 2020

Revised on 16 July 2020

Accepted on 18 July 2020

The journal allows the authors to hold the copyright

without restrictions and

allow the authors to retain

publishing rights without

restrictions. Authors retain

copyright and grant the

journal right of first

publication with the work

simultaneously licensed

under a creative commons

attribution 4.0 international

license.

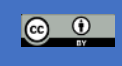

DOI: 10.37479

\section{ABSTRACT}

Purpose: An investor always needs accounting information in determining an investment decision. Accounting information relates to many matters relating to the Company's activities in certain periods. The research aims to test and analyse the relevance of accounting information, corporate social responsibility and leverage as moderation variables.

Design/Methodology/Approarch: The study population of 11 banking companies registered in the IDX period was 2015 - 2018 with a sample number of 44 observations. This sampling technique uses the purposive sampling method. This research hypothesis test uses multiple linear regression with the Moderated Regression Analyys (MRA) approach. Independent variables in this study are the value of profit, book value, and corporate social responsibility. Leverage as a moderation variable and stock price as the dependent variable.

Findings: The results of this study show that the value of profit, book value and corporate social responsibility affect the stock price. Leverage as a moderation variable can strengthen the book value relationship to the share price, but it cannot strengthen the value of profit relationship to the share price and corporate social responsibility towards the share price. It can be concluded that the value of profit, book value and corporate social responsibility has the relevance of accounting information value. Leverage as a moderation variable can only strengthen the book value relationship to the share price. The degree of research is expected to increase the amount of data samples to achieve more significant results.

Keywords: Earning; Book Value; CSR; Leverage; Value Relevance

\section{INTRODUCTION}

The company utilizes the capital market as one of the places to find funds to finance its efforts. In addition, the capital market is also used to raise funds from the community by investing funds into companies 
whose activities are healthy and can provide a profitable return. For investors, the capital market is a means of providing various investment options in accordance with the preference of investors.

The establishment of an efficient capital market can be seen from the important role of accounting information. Accounting information as a basis and supporting the decision of a company's decisions. While the efficient capital market can be achieved if the stock price reflects all relevant information. So that a relevant accounting information will determine a decision making to the efficient capital market activity.

According to (Herlianto, 2008) stock price is the price of a stock in the stock market at a certain period of time conducted by market participants, other than that the stock price is also determined on the basis of the demand and supply of the relevant stock in the capital market.

Accounting information is said to have a value relevance if such accounting information can be used as the basis for predicting the company's market value. Thus, the relevance of accounting information values illustrates the role of accounting information as the basis in investment decision making (Barth et al., 2001). In other words, accounting information that can affect decision making is relevant information.

The financial statements issued by the company must be relevant information that is, the information is able to reveal the actual condition of the company, so it is beneficial to the public interest. The indicator that an accounting information is relevant is to observe the reaction of an investor at the time of the announced information that is reflected from the change in the stock price in a certain period (Naimah, 2014).

In the concept of the relevance of accounting information value explains how investors react when the announcement of accounting information contained in financial statements. The reaction of the investor will prove that the accounting information content is a very important issue in the process of consideration of investment decision making (Beaver, 1968).

Research on the relevance of accounting information values generally uses models introduced by Ohlson, 1995. The use of the Ohlson model illustrates how the relationship between the book value and other information is suspected to affect the price of the stock. Thus, the Ohlson model provides a testable equation on the role of financial and non-financial information in determining the company's market value (Bugshan, 2005).

(Feltham \& Ohlson, 1995) in his research stating clean surplus theory is a fundamental theory of the value of accounting information. This theory states that the company's value is reflected in the accounting 
information contained in the financial statements. Based on clean surplus theory, the stock market price is reflected in the profit/loss and balance statement.

In (Feltham \& Ohlson, 1995) Research also mentioned that the company's market value can be understood as the aggregation profit of companies expected in the future and the value of the company's equity book expected in the future. The expected profit in the future will provide enough information to calculate the present value in determining the value of the company. Thus, the value of the equity book and the profit value are the underlying variables used to determine the value of the company. The research conducted by (Agusti \& Rahman, 2011), a clean surplus model is also determined by the presence of information asymmetry. In overcoming the asymmetric information of apparently by conducting disclosure. One disclosure that can be done is disclosure of corporate social responsibility activities.

The relevance value illustrates how important the use of financial reporting information for market participants is relative to all information used by market participants in the capital market. Important components in financial statements that are often used as tools to inform the company's performance are the value of profit and value of the book (Ball \& Brown, 1968).

The value of profit and the book value is often used as a tool to measure the performance of the company, the value of profit and the book value is often chosen to be the main variable in the accounting information contained in the financial statements (Ball \& Brown, 1968). The value of profit and value of the book has a relevance value when statistically related to the decline or increase in stock prices.

Corporate profit is one of the information that market participants often use in analyzing stock prices. According to Suwardjono (2008) profit is considered to contain information if the stock market reacts to the announcement of profit, then if the accounting profit of a company indicates the change in the increase then the investor will be interested to invest his funds in the company. So if the stock price has increased, so the stock return will increase as well. The increased company profit will affect the value of the company that will increase. Therefore, profit can be used by market participants to analyse the stock price.

According to Hartono (2003), the book value per share represents net assets owned by shareholders by having one share sheet. Since the net asset is equal to the total shareholder equity, the book value per share is the total equity divided by the number of shares in circulation.

The value of this book per share indicates a net asset value per share owned by the holder. In addition, the value of the book can also reflect how much guarantee the shareholder will obtain if the issuer's 
company is liquidated. The equity book value is the value of shares according to the company's bookkeeping.

Corporate Social Responsibility Disclosure is the disclosure of corporate social activity that is expected to influence public perception of the company and affect the company's financial performance. The disclosure of corporate social responsibility is a process that provides information to raise problems around social accountability and this action can be held accountable in the media such as annual report or the Sustainability report (Gray et al., 2001).

Generally if the larger the company then pressure from stakeholders to the provider of goods or services that are quality, safe, and environmentally friendly by the company will be bigger. With such rules, the disclosure of corporate social responsibility is a reflection of the importance of accountability of the company for the disclosure of social responsibility so that stakeholders can assess the activity of the company in order to make better decision making. In addition, corporate social responsibility is not only related to environmental issues but also ethical and moral issues.

Corporate Social Responsibility disclosure is a disclosure of information about the social activity that the company expects to be able to influence investor perception of the company and affect the company's financial performance.Generally if the larger the company then pressure from stakeholders to the provider of goods or services that are quality, safe, and environmentally friendly by the company will be bigger. With such rules, the disclosure of corporate social responsibility is a reflection of the importance of accountability of the company for the disclosure of social responsibility so that stakeholders can assess the activity of the company in order to make better decision making. In addition, corporate social responsibility is not only related to environmental issues but also ethical and moral issues.

Legitimacy theory can describe Corporate Social Responsibility because the company can be within the community because of the support of the surrounding community. Therefore, the behavior and the manner in which the company runs the business should be in the guidelines applied to the community. Legitimacy is a corporate management system oriented towards the society, both government, individuals, and community groups. Therefore, as a system that puts forward the alignments to the society, the operation of the company must be congruent with the expectations of the community.

According to Irawati(2006), leverage is a policy done by a company in the event of investing funds or obtaining a source of funds accompanied by a fixed burden/expense that the company must bear. The use of assets and sources of funds by companies that have a fixed cost (fixed load) means the source of the funds derived from the loan because it has a fixed load interest with the intention of increasing the 
potential profit of the shareholder. Leverage is also the ability of the company to use fixed assets or funds to increase the return level for the company owner.

Leverage shows the magnitude of the assets that the company has derived from the debt or capital, so that the company can know the financial situation and the obligation of a fixed company to the other party and balance the value of fixed assets with existing capital (Brigham \& Houston, 2006). Thus, the leverage of a company can affect the return of shares which will also affect the share price of the company itself because in general the investors look at the condition of the company with a low leverage better than the company with high leverage because of the low leverage reflecting the use of debt and other liabilities smaller to finance the company's assets. If a company has a high leverage, the company will be overwhelmed with a high cost of debt that has an impact on the decline in the company's profit so that it affects the price of the stock.

Leverage is chosen as a moderate variable in the study because it is predicted to affect stock prices. Leverage is an instrument that is very sensitive to changes in corporate values. The higher the proportion of debt a company is the higher the price of the company's shares, but at some point the increase in debt will decrease the value of the company (Chen et al., 1999).

Based on explanation above, this research aims to analyze the relevance of accounting information and corporate social responsibility with leverage as moderation variable.

\section{METHODS}

This research is a type of quantitative study. This research uses secondary data. The data source is derived from the financial statements of the company's banking sector listed on the Indonesia Stock Exchange. The population in this research is a banking sector company listed on the Indonesia Stock Exchange (IDX) period 2015 - 2018. Sampling techniques using the purposive sampling method with the research criteria is a company go public the banking sector registeredin IDX period 2015 - 2018, issued an annual report for year observations, published The Sustainability Report for year of observation, and company which does not use foreign currency in reporting financial statements (uses Indonesian Rupiah).

The study used multiple regression analyses with Multiple Regression Analysis (MRA). Hypothesis test using Partial Least Square (PLS) with software WarpPLS 7.0 This research uses multiple regression analysis with Multiple Regression Analysis (MRA). Hypothesis test using Partial Least Square (PLS) with software WarpPLS 7.0. 


\section{Variablel Research and operational definitions}

The variables in this study are:

a. Bound variable (Y) stock price

b. Moderating variable $(\mathrm{Z})$ leverage

c. Free variable $(\mathrm{X})$ i.e. earning, book value, and corporate social responsibility

The operational definitions in this study can be described as follows:

a. Stock Price $(\mathrm{Y})$

Stock prices are prices on stock exchanges at specific times specified by market participants and by corresponding stock supply and demand in the capital market. The share price used in this research is the stock price closing 5 days after the published financial report (Meidawati and Mahendra, 2004).

b. Leverage $(\mathrm{Z})$

The ratio of the laverage showed that the company's funds were budget-funded (Sutrisno, 2013:224). In this study the ratio of laverage was measured using debt ratio. This ratio compares between the total debt companies has with the total assets (cashmere, 2014:151). Here's the indicator:

Debt Ratio:

$$
\frac{\text { Total debt }}{\text { Total Assets }}
$$

c. Earning (X1)

In this study used net income per share, which is net revenue per stock sheet at the end of fiscal year. Here's the indicator:

Earning Per Sahre:

Net income

$\overline{\text { Weighted Average Shares Outstanding }}$

d. Book Value (X2)

The value of the book is the net asset owned by the investor by having one share sheet (Indra and Sham, 2004). The value of the book per share used in this study is the value of ordinary stock books at the end of fiscal year. The book value per share is the total equity divided by the number of outstanding shares (Hartono, 2009). Here's the indicator:

Total Asset Turnover Ratio:

\section{$\frac{\text { Stakeholders Equity - Preferred Stock }}{\text { Average Share Outstanding }}$}

e. Corporate Social Responsibility (X3)

The disclosure of Corporate Social Responsibility (CSR) is a disclosure of information about corporate social responsibility 
published on annual report or Sustainability report. CSRI (Corporate Social Responsibility Indexs) Measuring instruments are conducted using the dichotomy approach. Here's the indicator: Corporate Social Responsibility Indexs :

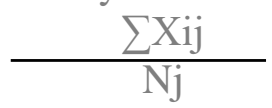

Information:

CSRIj : Corporate Social Responsibility Disclousure Index ¿Xij : Total number or score obtained by each company Dummy variabel : $1=$ if item i disclosed, and $0=$ if item $\mathrm{i}$ not disclosed.

$\mathrm{Nj}$ : Number of items for the company $\mathrm{j}$.

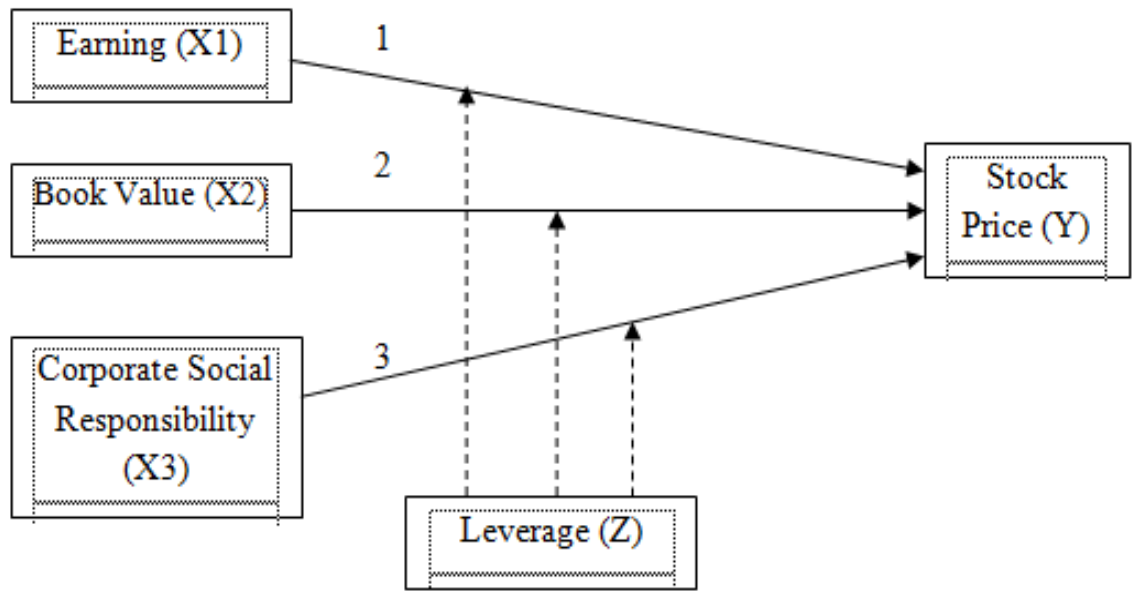

Picture 1. Hipotesa

Hypotheses

Hypotheses in this study are as follows:

H1 : Earning affects the stock price

$\mathrm{H} 2$ : Book value affects the stock price

H3 : Corporate Social Responsibility affects the stock price

H4 : Leverage moderate earning value affects to the stock price

H5 : Leverage moderate book value affects to the stock price

H6 : Leverage moderate corporate social responsibility affects to the stock price

\section{RESULTS}

\section{Outer Model Test}

The Outer model is a measurement for assessing the validity and reliability of the model. 


\section{Test Validity}

A validity test is a test used to indicate the extent to which the measuring instrument is used in a measure of what is measured. Ghozali (2009) states that the validity test is used to measure legitimate, or whether or not a valid data.

In PLS-SEM using program WarpPLS, to measure the validity of a construct can be done by testing the validity of converegent and dicriminant.

\section{Convergent Validity and Discriminant Validity}

Convergent validity is measured by viewing the outer loading value of each indicator. Rule of thumb which usually used to assess the validity of converegent which is the value of loading factor must be more than 0.7 for the research that confirmatory and the value of loading factor between $0.6-0.7$ for exploratory research is still acceptable and the average value of variance exstracred (AVE) must be greater than 0.5 .

Discriminant validity measured using cross-loading. An indicator is said to meet the discriminant validity if the value of cross loading indicators against the variable is the largest compared to other variations. The way to test linear validity is to see the cross loading value for each variable to be $>0.70$. Another possible way to test the validity of linear is to compare the square roots of the AVE to each construction with the correlation value between the construction in the model. Convergent Validity and Discriminant Validity test results can be shown in the following table:

Tabel 1.

Combined Loadings and Cross-loadings

\begin{tabular}{ccccccccc}
\hline & N.Laba & N.Buku & CSR & Leverage & H.Saham & Lev*Laba & Lev*Buku & Lev ${ }^{*}$ CSR \\
\hline $\mathbf{X} 1$ & $(1.000)$ & -0.346 & -0.043 & 0.141 & -0.405 & 0.025 & 0.122 & -0.150 \\
$\mathbf{X} \mathbf{2}$ & -0.346 & $(1.000)$ & 0.038 & -0.380 & 0.558 & 0.326 & -0.326 & 0.376 \\
$\mathbf{X} 3$ & -0.043 & 0.038 & $(1.000)$ & 0.061 & 0.066 & -0.068 & 0.064 & 0.308 \\
$\mathbf{Z}$ & 0.141 & -0.380 & 0.061 & $(1.000)$ & -0.056 & -0.986 & 0.998 & -0931 \\
$\mathbf{Y}$ & -0.405 & 0.558 & -0.066 & -0.056 & $(1.000)$ & -0.011 & -0.022 & 0.029 \\
Lev $*$ Laba & 0.025 & 0.326 & -0.068 & -0.986 & -0.011 & $(1.000)$ & -0.988 & 0.915 \\
Lev*Buku & 0.122 & -0.326 & 0.068 & 0.998 & -0.022 & -0.988 & $(1.000)$ & -0.928 \\
Lev ${ }^{*}$ CSR & -0.150 & 0.376 & 0.308 & -0.931 & 0.029 & 0.915 & -0.928 & $(1.000)$ \\
\hline
\end{tabular}

The loading factor illustrates how much of the indicators are associated with each one - its construction. The results of WarpPLS data in the table 1 shows that all indicators have loading factor 1,000 which means that all indicators are valid because the value of loading factor meet the criteria is the value of loading factor must be above 0.70 and this result indicates a good linkage between indicatorsindicator with each of the construction. 
From cross loadings results all indicators are high correlate with each - each of the conduits. Cross Loadings explains how powerful the indicators are - the indicators of each latent (Construk) variable. The results of data processing warppls in Table 4.1 shows that all indicators have a cross loadings 1,000 which means that all indicators are measured from the validation is already said to be valid because the value of cross loadings meet the criteria of the value of cross loadings construct must be above 0.70 and this result indicates a good linkage between indicators-indicator with each construk.

\section{Reliability Test}

Reliability test is done to prove the accuracy, consistency and accuracy of the instrument in measuring the construction. In PLSSEM using WarpPLS program, to measure the reliability of a construct can be done in two ways namely with Cronbach's Alpha and Composite Reliability.

\section{Cronbach's Alpha Test}

The Rule Of thumb that is usually used to assess the reliability of the Cronbach Alpha should be greater than 0.7 for Confirmatory-based research and the 0.6 value is still acceptable for exploratory researchers. Cronbach's Alpha test results can be shown in the following table:

\begin{tabular}{cc} 
Cronbach's Alpha Test Results \\
\hline Variable & Cornbach Alpha \\
\hline Earning (X1) & 1.000 \\
Book Value (X2) & 1.000 \\
CSR (X3) & 1.000 \\
Leverage ( $Z)$ & 1.000 \\
Stock Price (Y) & 1.000 \\
Leverage*Earning & 1.000 \\
Leverage*Book Value & 1.000 \\
Leverage*CSR & 1.000 \\
\hline
\end{tabular}

In the table 2 shows the Cronbach Alpha value of each research variable $1.000>0.7$ then these results can be noted that each research variable has fulfilled the requirements of Cornbach Alpaha value, so it can be concluded that the overall variable has a high degree of reliability.

\section{Composite Reliability Test}

Composite reliability (sometimes called construct reliability) is a measure of internal consistency in scale items, much like Cronbach's alpha (Netemeyer et al., 2003). It can be thought of as being equal to the total amount of true score variance relative to the total scale score variance (Brunner \& SÜ $\beta, 2005)$. Alternatively, it's an "indicator of the shared variance among the observed variables used as an indicator of a latent construct" (Fornell \& Larcker, 1981). 
Rule Of thumb which is usually used to assess the reliability of the countermeasure of Composite Reliability should be greater than 0.7 for Confirmatory-based research and $0.6-0.7$ value is still acceptable for exploratory researchers (Latan and Ghozali, 2012). Composite Reliability test results can be shown in the following table:

Table 3.

Composite Reliability Test Results

\begin{tabular}{cc}
\hline Variable & Composite Reliability \\
\hline Earning (X1) & 1.000 \\
Book Value (X2) & 1.000 \\
CSR (X3) & 1.000 \\
Leverage (Z) & 1.000 \\
Stock Price (Y) & 1.000 \\
Leverage*Earning & 1.000 \\
Leverage*Book Value & 1.000 \\
Leverage*CSR & 1.000 \\
\hline
\end{tabular}

All of Composite Reliability research variables $1.000>0.7$ then these results indicate that each variable has fulfilled the composite reliability so that it can be concluded that the overall variable has a high degree of reliability.

\section{Inner Model Test (Goodness of Fit Test)}

The Inner model is a structural model to predict the causality relationship between the latent variables. Through the bootstraping process, the T-Statistic test parameter is obtained to predict the presence of causality relationships.

Evaluate the value of R2 that demonstrates the magnitude of the variability of endogenous variables that are capable of being described by exogenous variables. Value coefficient of determination (R-squared) 0.75 ; 0.50; and 0.25 for each endogenous latent variable in the structural model can be interpreted as substantial, moderate, and weak. These measuring models can help researchers assess the significance of hypotheses the researchers ask. The Inner model test results can be shown in the following table:

Tabel 4.

Goodness of Fit Test

\begin{tabular}{ccc}
\hline Variable & Nilai R-Square & Nilai Q-Square \\
\hline Stock Price $(\mathrm{Y})$ & 0.464 & 0.453 \\
\hline
\end{tabular}

The R-Square value of the stock price variable is 0464. The acquisition of the value explains that $46 \%$ of the stock price is affected 
by the profit value, book value and CSR variables. The rest will be affected by variable variables.

The Q-Square value for the share price variable is 0453 . This suggests that the model of this research can be stated to have had a fairly good goodness of fit.

\section{Hypothesis Test Results}

A hypothesis test is used to explain the direction of relationships between independent variables and its dependencies variables. This test is done by analyzing the path analysis of the model that has been created. SEM techniques can simultaneously test complex structural models, so that it can be known to track analysis results in a single regression analysis. The correlation between the construction is measured by looking at the coefficients path and its significance level which is then compared to this research hypothesis. A hypothesis can be accepted or should be rejected statistic can be calculated through its significance level. The significance level used in this study was $5 \%$. If the significance level is selected by $5 \%$ then the significance or confidence level is 0.05 to reject a hypothesis. In this study there was the possibility of taking an incorrect decision of 5\% and the likelihood of making a correct decision of $95 \%$. The basis of decision making i.e. P-value $\leq 0.05$ hypothesis received otherwise $\geq 0.05$ hypothesis rejected.

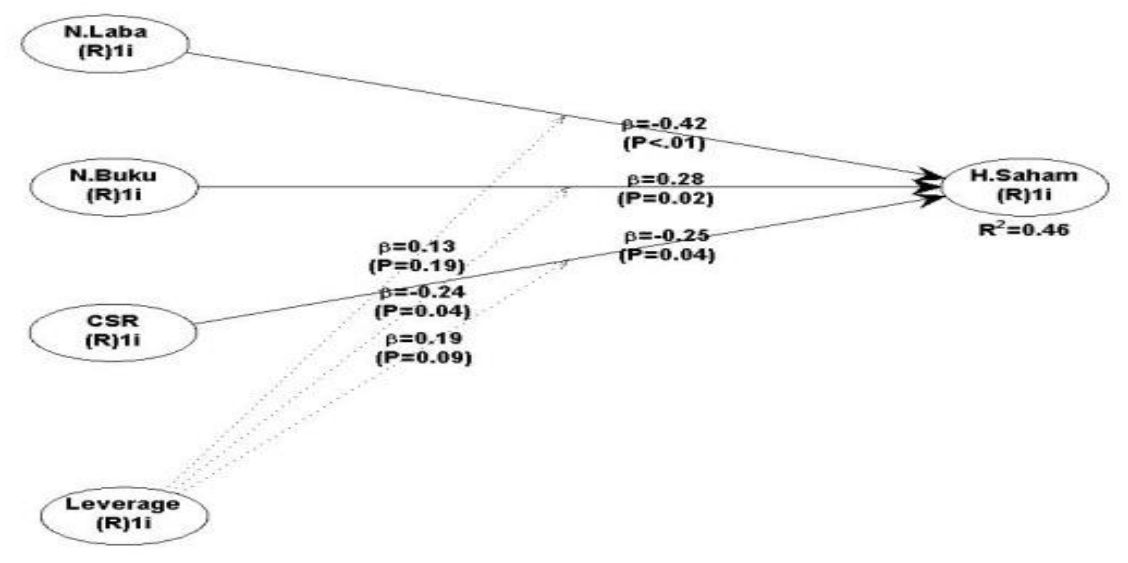

Figure 2. Results of the research Model

Table 5. Tabulation of estimated results of the research Model

\begin{tabular}{lccc}
\multicolumn{2}{c}{ Table 5. Tabulation of estimated results of the research Model } \\
\hline \multicolumn{1}{c}{ Variable } & $\begin{array}{c}\text { Koefisien Jalur } \\
(\boldsymbol{\beta})\end{array}$ & p-value & Keterangan \\
& 0.42 & $\mathrm{P}<0.01$ & Significant \\
\hline Earning $\rightarrow$ Stock Price & 0.28 & $\mathrm{P}=0.02$ & Significant \\
Book Value $\rightarrow$ Stock Price & 0.25 & $\mathrm{P}=0.04$ & Significant \\
$\mathrm{CSR} \rightarrow$ Stock Price & 0.13 & $\mathrm{P}=0.19$ & Not significant \\
Leverage*Earning $\rightarrow$ Stock Price & 0.24 & $\mathrm{P}=0.04$ & Significant \\
Leverage*Book Value $\rightarrow$ Stock & & & \\
Price & 0.19 & $\mathrm{P}=0.09$ & Not significant \\
Leverage*CSR $\rightarrow$ Stock Price & & & \\
\hline
\end{tabular}


The hypothesis test is said to be significant when the significance value is $<0.05$. Research results presented in the table 8 indicate that the profit value affects the share price with a P-value of $0.01<0.05$. The book value affects the share price with a P-value value of $0.02<$ 0.05. Corporate Social Responsibility affects the price of the share with a P-value of $0.04<0.05$. Leverage does not moderate the value of profit against share prices due to $\mathrm{P}$-value value of $0.19>0.05$. Leverage moderate the relationship between the value of the book against the stock price, because the $\mathrm{P}$-value value is $0.04<0.05$. Leverage does not moderate the corporate social responsibility relationship to the stock price, due to the P-value of $0.09>0.05$. Then it can be concluded that the leverage as a moderation variable is able to strengthen the book value relationship to the share price but can not strengthen the value of profit relationship to the share price and corporate social responsibiity towards the stock price.

\section{DISCUSSION}

Based on the results of this study can be known that hipotesa 1 the earning value variable affects the value of the stock price. This can be due to the value of profit having the information that can be used to determine the price of the stock, so that the investor will see the company that is proscribed on profit-based. If the value of the profit is high then the company's performance is well assessed and the stock price will move up, and vice versa. Thus Earning Per Share (EPS) is instrumental in the decision making of investors in choosing to invest.

Hipotesa 2 variable books value has effect stock prices. This can be due to indications that in assessing the performance of a future prospect, an investor will use the book's value information because the book value reflects the value of the company, and the company's value is reflected in the economical net worth value. In addition, the book value information will be reflected in the stock market price. Therefore, the subject matter of the value of the book owned by a company used for investment decision making will affect the stock price of the company's capital market.

Hipotesa 3 indicates that the variable corporate social responsibility affects the stock price. This means that companies implementing CSR is an investment for the company and sustainability is no longer seen as cost. It can certainly be a reference for investors in consider companies that conduct Corporate Social Responsibility disclosures as part counts in decision making 40 Investment, because companies that conduct Corporate Social Responsibility disclosures means paying attention to business sustainability.

Based on the results hipotesa 4 indicates that the leverage as a moderation variable cannot strengthen the relationship between the value of the profit earning to the stock price. Leverage as a ratio in analyzing the company's ability to pay its debts will not affect the value of profit on the share price. This can be due to the absence of 
information on the leverage does not affect the company's Leba in determining the stock price. This can happen because investors in Indonesia is believed to still not utilize the maximum financial information that has been published in its investment decisionmaking, as it is believed that most Indonesian investors are speculated investors who have more funds without being accompanied by knowledge and skills in investing.

Hipotesa 5 indicates that the leverage as a moderation variable can strengthen the relationship between the book value against the stock price. This can be due to the leverage can be measured by the value of the book whereby the financial leverage based on the book value is measured by the ledger value of the entire debt to total assets. So in this case leverage can help strengthen the relationship between the value of the book against the stock price.

Hipotesa 6 indicates leverage that does not affect corporate social responsibility and stock prices of most companies using the funds to pay the debt from the costs associated with the Social disclosure.

\section{CONCLUSION}

This research is conducted with the aim to test and analyze the relevance of accounting information and corporate social responsibility with leverage as a moderation variable in the banking sector company. The study used samples of 11 companies of the enmational sector listed on the IDX period 2015 - 2018 through multiple linear regression analyses. Number of data observations of 44 observation data. This result show, the first hypothesis shows that the value of profit affects the stock price, thus the relevance of the value of the profit value accounting can determine the stock price of a company. The second hypothesis suggests that the book's value affects the stock price, thus the relevancy of the ledger value accounting information can determine the stock price of a company. The third hypothesis suggests that corporate social responsibility affects the share price, thus the relevance of the value of accounting information corporate social responsibility can determine the stock price of a company. The fourth hypothesis shows that leverage as a moderation variable cannot strengthen the relationship between the value of the profit to the stock price. The fifth hypothesis suggests that leverage as a moderation variable cannot strengthen the relationship between the book's value against the share price. The sixth hypothesis shows that leverage as a moderation variable cannot strengthen the relationship between corporate social responsibility towards stock prices. For investors, as a matter of consideration in taking decisions or policies in investing. Researchers will then be able to study the observation samples to get more maximum results.

\section{RECOMMENDATION}

Based on the conclusion above, then in this research researchers are expected to add independent variables such as cash flows and 
moderation variables such as Corporate Governance. For further researchers to research on other sector companies outside the banking sector to know the consistency of factors that affect the relevance of accounting information value.

\section{REFERENCES}

Agusti, R. R., \& Rahman, A. F. (2011). Relevansi Nilai Laba dan Nilai Buku: Peran Pengungkapan Corporate Social Responsibility dan Dewan Komisaris Independen. Simposium Nasional Akuntansi XIV Aceh.

Ball, R., \& Brown, P. (1968). An empirical evaluation of accounting income numbers. Journal of Accounting Research, 159-178.

Barth, M. E., Beaver, W. H., \& Landsman, W. R. (2001). The relevance of the value relevance literature for financial accounting standard setting: another view. Journal of Accounting and Economics, 31(1-3), 77-104.

Beaver, W. H. (1968). The information content of annual earnings announcements. Journal of Accounting Research, 67-92.

Brigham, E. F., \& Houston, J. F. (2006). Dasar-dasar manajemen keuangan. Jakarta: Salemba Empat.

Brunner, M., \& SÜ $\beta$, H.-M. (2005). Analyzing the reliability of multidimensional measures: An example from intelligence research. Educational and Psychological Measurement, 65(2), 227-240.

Bugshan, T. (2005). Corporate governance, earnings management, and the information content of accounting earnings: Theoretical model and empirical tests. Unpublished PhD Thesis, Bond University, Australia.

Chen, C. R., Mohan, N. J., \& Steiner, T. L. (1999). Discount rate changes, stock market returns, volatility, and trading volume: Evidence from intraday data and implications for market efficiency. Journal of Banking \& Finance, 23(6), 897-924.

Cronbach, L. J. (1951). Coefficient alpha and the internal structure of tests. Psychometrika, 16(3), 297-334.

Eley, T. C., Sugden, K., Corsico, A., Gregory, A. M., Sham, P., McGuffin, P., Plomin, R., \& Craig, I. W. (2004). Geneenvironment interaction analysis of serotonin system markers with adolescent depression. Molecular Psychiatry, 9(10), 908915.

Feltham, G. A., \& Ohlson, J. A. (1995). Valuation and clean surplus accounting for operating and financial activities. Contemporary Accounting Research, 11(2), 689-731. 
Fornell, C., \& Larcker, D. F. (1981). Evaluating structural equation models with unobservable variables and measurement error. Journal of Marketing Research, 18(1), 39-50.

Ghozali, I. (2009). Ekonometrika: teori, konsep dan aplikasi dengan SPSS 17. Semarang: Badan Penerbit Universitas Diponegoro.

Gray, R., Javad, M., Power, D. M., \& Sinclair, C. D. (2001). Social and environmental disclosure and corporate characteristics: A research note and extension. Journal of Business Finance \& Accounting, 28(3-4), 327-356.

Hartono, J. (2003). Teori Portofolio dan Analisis Investasi Edisi Kelima. Yogyakarta: BPFE.

Herlianto, D. (2008). TEORI FORTOFOLIO DAN ANALISIS INVESTASI.

Irawati, S. (2006). Manajemen keuangan. Bandung: Pustaka.

Naimah, Z. (2014). Relevansi nilai informasi akuntansi: Suatu kajian teoritis. Buletin Studi Ekonomi, 44258.

Netemeyer, R. G., Bearden, W. O., \& Sharma, S. (2003). Scaling procedures: Issues and applications. Sage Publications. 